

\section{DISCLAIMER}

This report was prepared as an account of work sponsored by an agency of the United States Government. Neither the United States Government nor any agency Thereof, nor any of their employees, makes any warranty, express or implied, or assumes any legal liability or responsibility for the accuracy, completeness, or usefulness of any information, apparatus, product, or process disclosed, or represents that its use would not infringe privately owned rights. Reference herein to any specific commercial product, process, or service by trade name, trademark, manufacturer, or otherwise does not necessarily constitute or imply its endorsement, recommendation, or favoring by the United States Government or any agency thereof. The views and opinions of authors expressed herein do not necessarily state or reflect those of the United States Government or any agency thereof. 


\section{DISCLAIMER}

Portions of this document may be illegible in electronic image products. Images are produced from the best available original document. 
This report was prepared as an account of work sponsored by the United States Government. Neither the United States nor the United States Department of

Energy, nor any of their employees, nor any of their contractors, subcontractors,

or their employees, makes any warranty, express or implied, or assumes any legal

liability or responsibility for the accuracy, completeness or usefulness of any in.

formation, apparatus, product or process disclosed, or represents that its use

would not infringe privately owned rights.

\section{PRINTED IN THE UNITED STATES OF AMERICA}

Available from

National Technical Information Service

U. S. Department of Commerce

5285 Port Royal Road

Springfield, Virginia 22161

Price: Printed Copy $\$ 4.00$; Microfiche $\$ 3.00$ 


\title{
Mound Laboratory Tritium Environmental Study: 1976-1977
}

\author{
Carl J. Kershner and T. Ben Rhinehammer
}

Issued: April 10, 1978

\section{MOUND FACILITY}

Mirmisburg, ahio 45342

operated by

\section{MONSANTO RESEARCH CORPORATION}

a subsidiany of Moneanto Compeny'

for the

\section{U. S. DEPARTMENT OF ENERGY}

Contract No. EY-76-C-04-0053

This repon was prepared as an account of work sponsored by the United States Govemment. Neither the United States nor the United States Department of Energy, nor any of their employees, nor any of their contractors, subcontractors, or their employees, makes any warranty, express or implied, or assumes any legal liability or responsibitity for the accuracy, completeness or usefulness of any information, epparatus, product or process disclosed, or represents that its use would not infringe privetely nwned rights. 


\section{Contents}

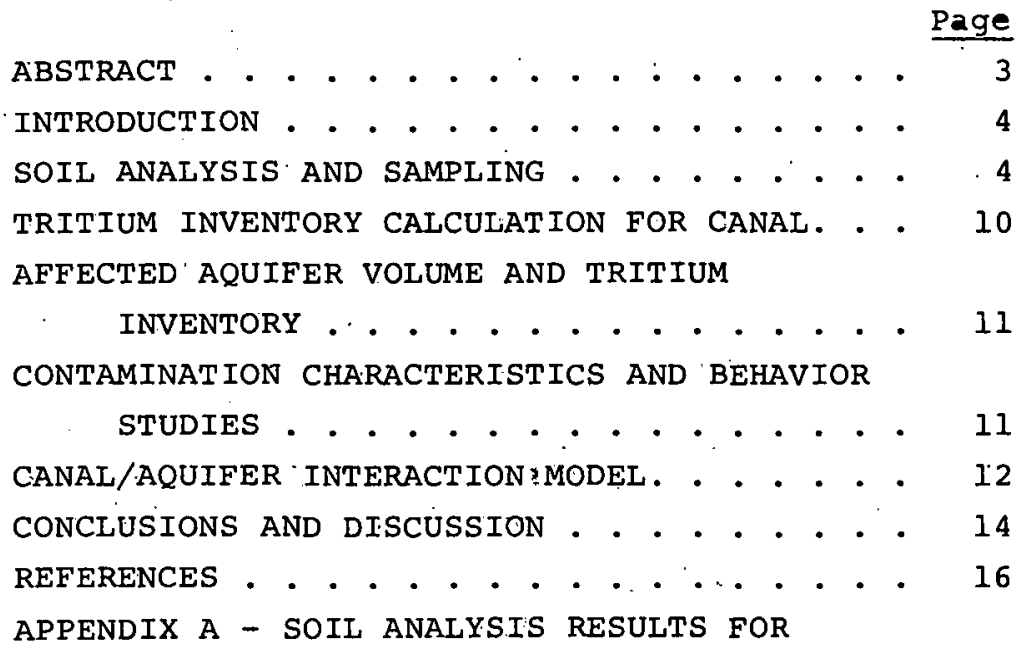




\section{Abstract}

In the course of an extensive investigation of tritium in the aquifer underlying the Mound Facility site, an unusual behavior was noted for a beta-emitting radionuclide contaminant present in the environs of the abandoned Miami-Erie Canal adjacent to the laboratory site. The soil contaminant was determined to be tritium, of which $90 \%$ was in the form of a relatively stable or "bound" species that was not readily exchangeable with the "free" water in the soil. (Bound-to-exchangeable transfer half-time was found to be approximately $3 \mathrm{yr}$.$) The$ contamination was found to be concentrated within two feet of the surface in the center of the canal channel and near the Facility site drainage ditch and canal confluence.

In order to characterize the contaminant and to assess its potential for reaching the aquifer, an analysis program and study were initiated in september 1976. The results and findings from the first phase of this work which was completed in February 1977 are the subject of this report.

A tritium inventory of approximately $200 \mathrm{Ci}(0.02 \mathrm{~g})$ as of December 1976 was estimated for the 5200-ft stretch of the canal adjacent to the Facility. However, its significance as a source term to the aquifer to which it contributes was calculated to be only $30 \mathrm{Ci}$ in the next year, since $90 \%$ of the contaminant was determined to be in the "bound" form.

On the basis of data obtained in the study of tritium concentrations in the aquifer over the past $5 \mathrm{yr}$ and a postulated three-compartment model for the canal/aquifer interactions, it was concluded that the time of maximum influence by the canal tritium has passed and the aquifer recharge dominates. Moreover, a modest pumping rate of $500 \mathrm{gal} / \mathrm{min}$ should produce an aquifer recharge that more than offsets the source terms from the canal. 


\section{Introduction}

Mound Facility is a research, development, and production facility operated by Monsanto Research Corporation for the Department of Energy (DOE). The site consists of 180 acres of land situated within the southern boundary of Miamisburg, Ohio, ' on an upland plateau overlooking the old Miami-Erie Canal and the Great Miami River, as shown in Figure 1 .

Since operations began in 1949, many radionuclides have been handled at the site. At the present, tritium and plutonium238 are of primary importance for the work supporting DOE weapons and radioisotopic heat source programs, respectively.

To ensure the safety of the operating personnel and the public, the Facility maintains an active control and monitoring program for all radionuclides being handled [1]. In the course of such an investigation. for tritium in ground water at and near Mound Facility, soil sample borings were taken in the abandoned Miami-Erie Canal area adjacent to the site. This canal area receives surface runoff water from a drainage ditch which flows through the onsite valley and was the subject of a previous plutonium-238 environmental study in which its topographical and hydrological features are thoroughly discussed [2]. Analyses performed by the Mound Facility Environmental Assessment and Planning Group showed tritium concentrations in the soil water distillates from these samples reached $186 \mu \mathrm{Ci} / 1 \mathrm{iter}$. In addition to being some three orders of magnitude higher in concentration than for ground water at other onsite and offsite locations, the tritium concentration in the canal soil distillates appeared to depend upon the temperature used for extraction. Distillate fractions taken above approximately $300^{\circ} \mathrm{C}$ exhibited the highest tritium concentration. These distillations were performed in flowing argon and exhibited considerable tar and heavy oil formation, especially for those soil samples containing relatively high organic (humus) content.

In order to more thoroughly investigate these findings and to determine if the tritium in the soil in the canal is or has the potential of contributing to the aquifer below it, a tritium environmental study was initiated in late september 1976. It is the purpose of this report to present the findings and conclusions from this study.

\section{Soil analysis and sampling}

In October 1976, Dames \& Moore, of cincinnati, ohio, an environmental and applied earth sciences consultants firm, was contracted to obtain soil boring samples from 12 locations in the section of the Miami-Erie Canal adjacent to the Mound Facility site and two background sample borings, one in the Miami-Erie Canal north of Dayton, Ohio, and one in a heavily reeded pond in Hamilton county, ohio.[3] In most cases the corings were taken to a depth of $60 \mathrm{in.}$ in 6-in. increments. Of the 12 canal sample locations, two cross sections consisting of three corings each were taken in both the north and south sections of the canal. The boring locations at each of the canal cross section positions consisted of one center location with two other locations near the bank on either side. The sample locations along the length of the canal and their estimated cross section distributions are shown in Figure 2. Sample 


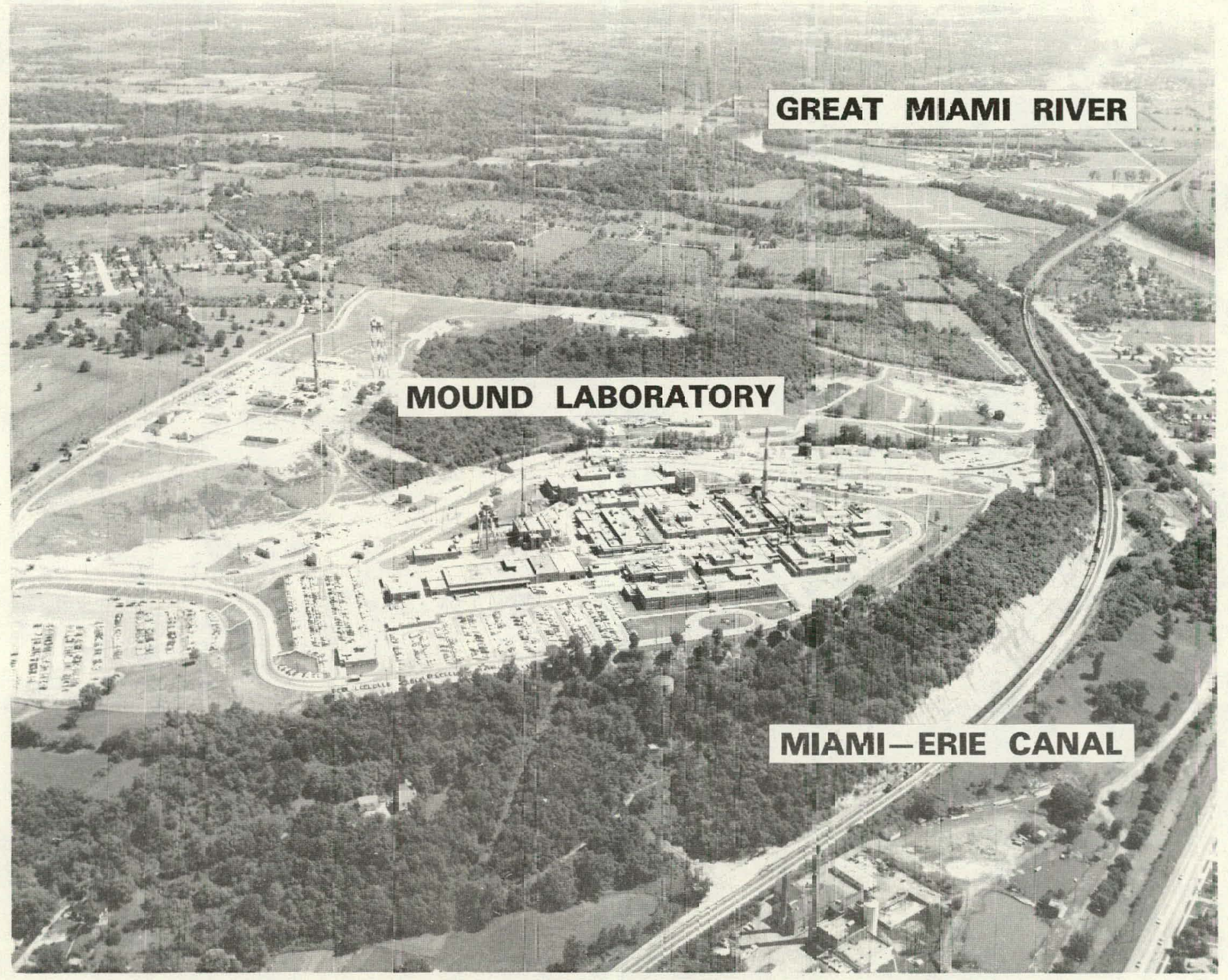

FIGURE 1 - Aerial view of Nound Facility, 


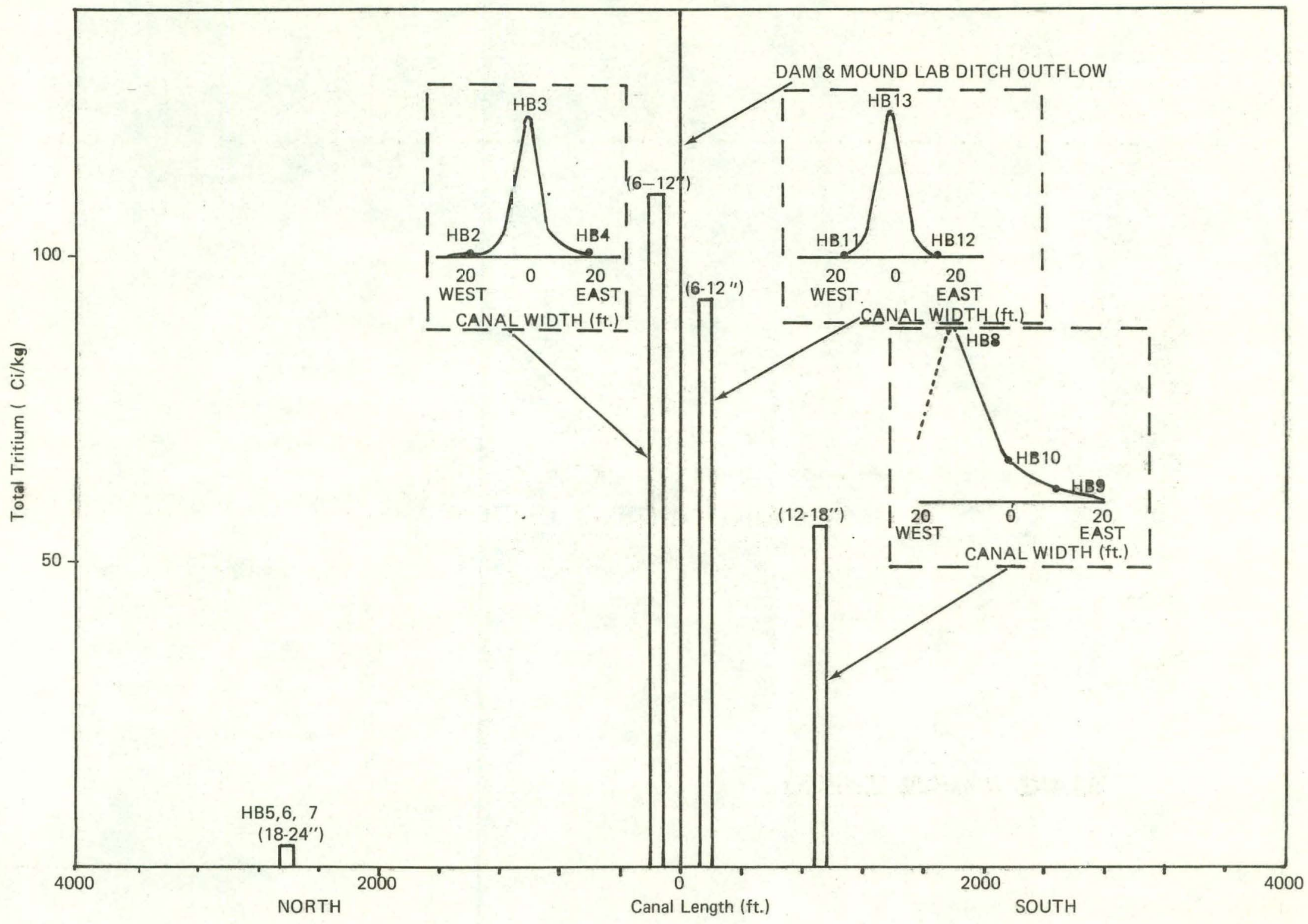

FIGURE 2 - Maximum total tritiun concentration at any depth along the Miami-Erie Canal . (Numbers in parentheses indicate depth at which maximum occurred.) 
The procedure developed to analyze these soil samples for tritium content was based on a pragmatic approach of determining the tritium content available and unavailable to migrate with the soil water. A water extraction technique was found to be applicable for separating the water-exchangeable portion (labile tritium) from the "bound". It was found that the tritium concentration in equal weight portions of soil and water would come to equilibrium within an hour and remain essentially constant for days. Based on these findings, the $\mathrm{HB}$ series of soil samples were analyzed by extracting the exchangeable tritium with a series of water leachings. Tritium concentrations were determined by standard liquid scintillation counting techniques. The total exchangeable tritium in the soil, which could include the "free" water, the adsorbed water, and most of the crystalline water, was determined in this way. After the water extraction, the soil samples were oven dried at $110^{\circ} \mathrm{C}$. It was found that once the exchangeable tritium was removed from the sample, essentially no tritium was lost from the soil samples at $110^{\circ} \mathrm{C}$. After oven drying, the samples were completely pyrolyzed at $900^{\circ} \mathrm{C}$ in a flowing oxygen atmosphere in order to convert all the bound tritium, organic or inorganic, to water. The resulting distillate was collected by condensatior. Ethylene glycol bubblers were used to trap any water vapor escaping from the condenser. Tritium contents for both the condensate and glycol bubbler were determiner by standard liquid scintillation counting techniques. The quantities of tritium found in the exchangeable and bound fractions were referenced to the oven-dried soil weight for comparison purposes.

The results of the $\mathrm{HB}$ series analyses have been plotted on bar graphs and are included in the Appendix of this report. The distribution summaries of these data are given in Figure 2. Profiles of $\mathrm{HB} 3$ and 13 plotted on a linear grid are shown in Figures 3 and 4 , respectively. The most salient features of these results are the very sharply peaked distribution profiles with respect to both the depth below the surface and the distance across the width of the canal. The highest concentration, found to be $110 \mu \mathrm{Ci} / \mathrm{kg}$ of soil, was for the 6-12 in. increment of $\mathrm{HB} 3$. In Figure 5 this is shown to be the area immediately north of where the drainage ditch enters the canal.

Several soil sample lots taken from the historical inventory maintained from the 1974 Plutonium Environmental study were analyzed for tritium [2]. Total tritium levels as high as $700 \mu \mathrm{Ci} / \mathrm{kg}$ have been found with depth distribution profiles resembling those of the plutonium-238 contamination. Because these soil samples were not taken in the same locations in the canal as the present $\mathrm{HB}$ series, they cannot be used directly for comparison of bound-to-exchangeable half-time estimates. The results do, however, indicate that there was tritium present in the canal in $19 \overline{7}$ in concentrations that appear to be considerably higher than at present. 


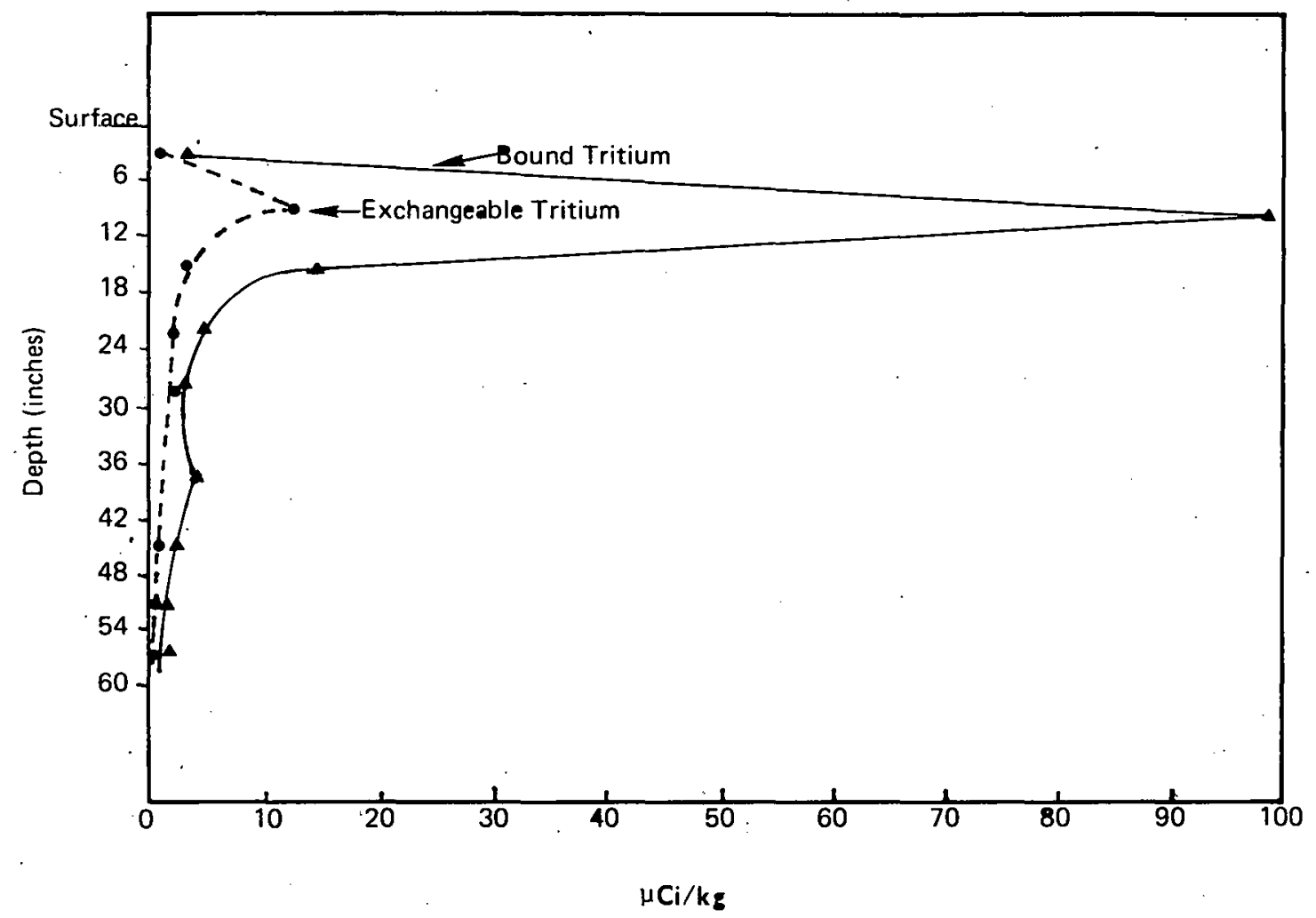

FIGURE 3 - Tritium depth profile HB3; center north canal; $150 \mathrm{ft}$ north of dam.

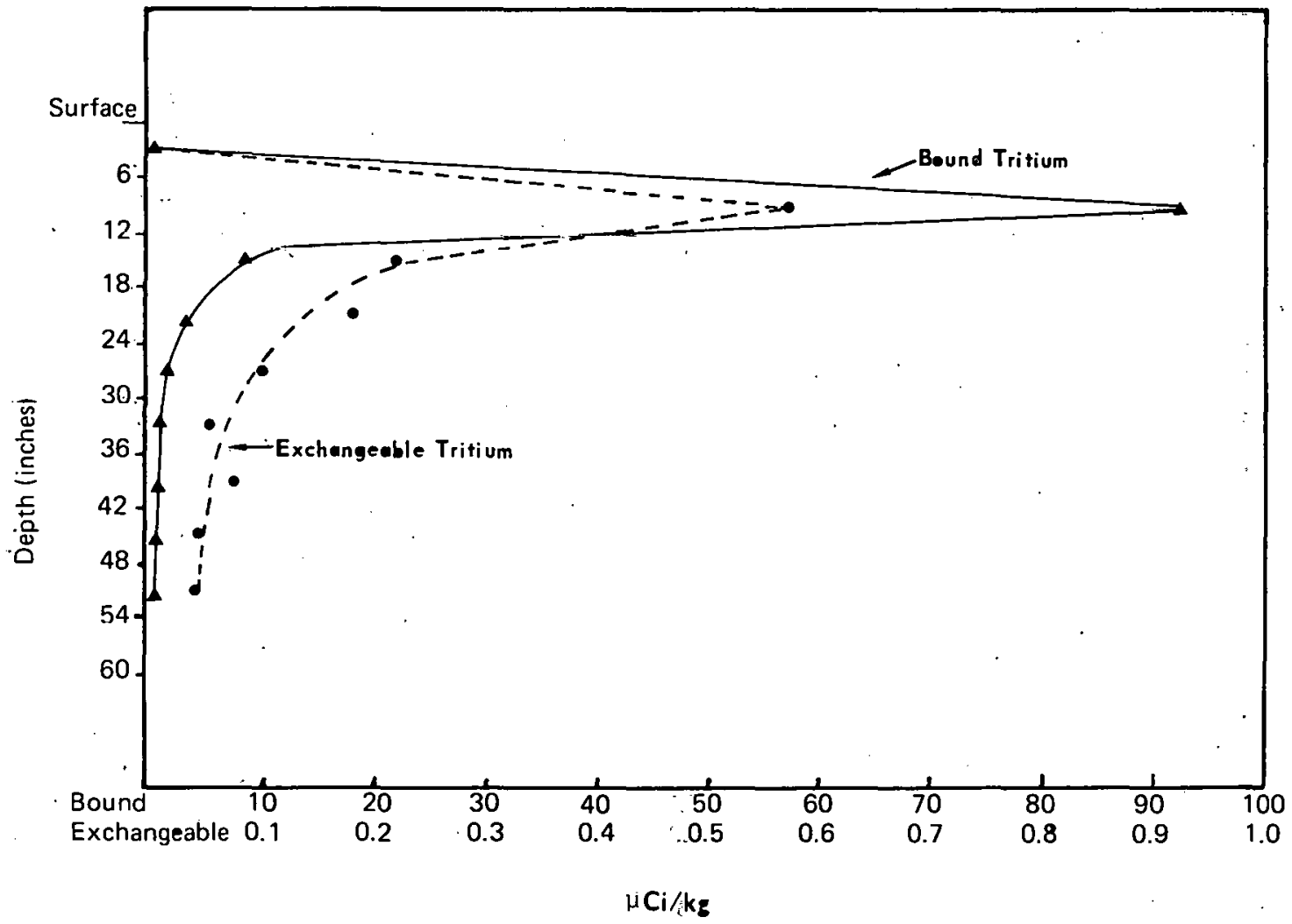

FIGURE.4 - Tritium depth profile HB13; center south canal; $150 \mathrm{ft}$ south of dam. 


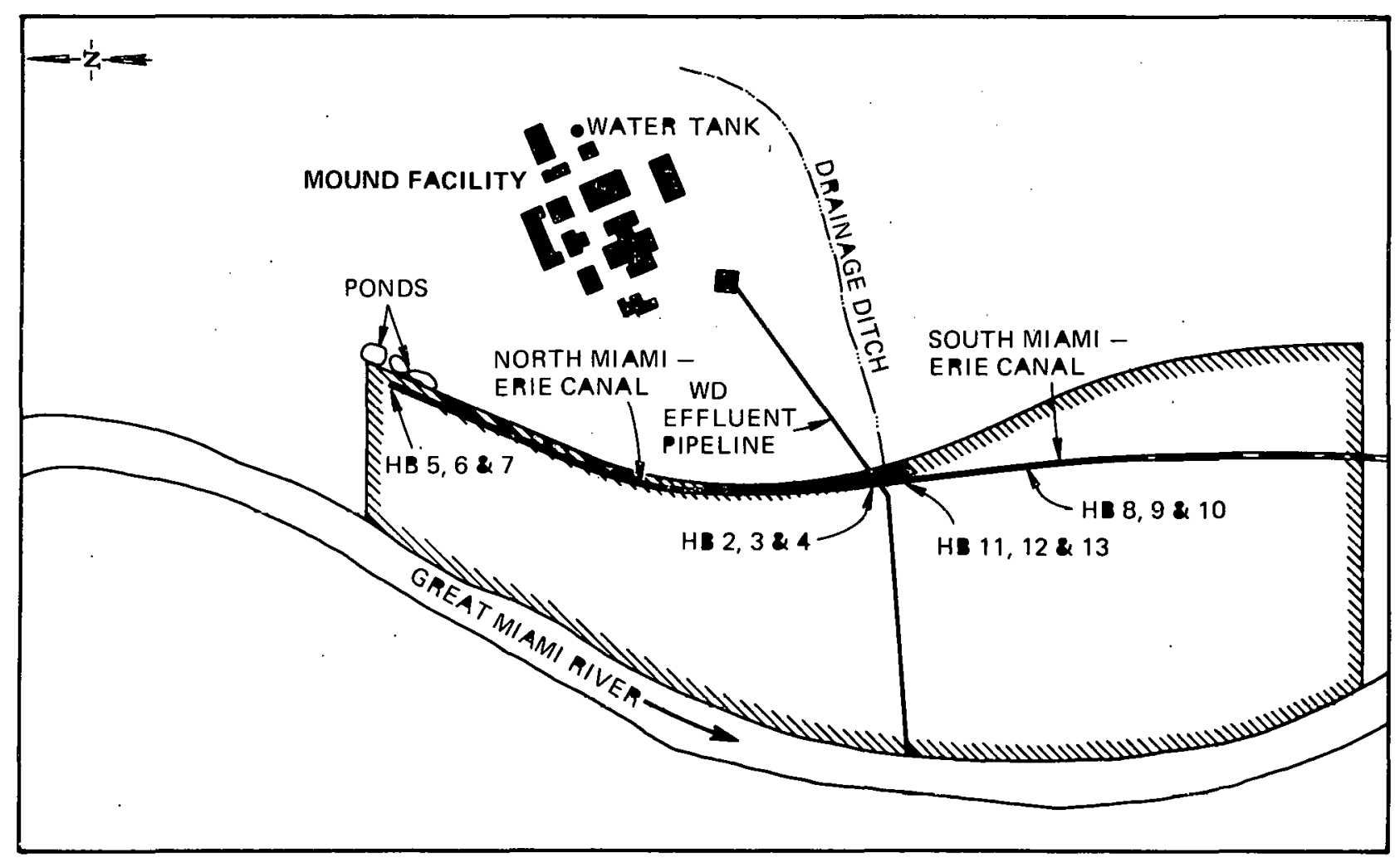

FIGURE 5 - Buried Valley Aquifer Affected by Canal. 
The results of the $H B$ series and the plutonium soil samples reveal a tritium contaminant that behaves quite differently from previous documented experience with tritiated water contamination in soil. In general, tritium as tritiated water has been found to follow the ground water movement with no significant isotopic fractionation or immobilization. The only appreciable fixation has been observed in an oak Ridge study where nonlabile tritium in soil has been attributed to fixation in organic material via plant metabolism [4].

\section{Tritium inventory calculation for canal}

An estimate of the tritium inventory in the Miami-Erie Canal and the adjoining ponds has been made using the analytical and distribution data from the HB series of soil samples. Since this soil analysis campaign represents a limited number of sample locations, a conservative approach was employed which should correspond to a maximum inventory value.

The following assumptions were made for this estimate:

1. Sample locations. HB3 and HBl3 are representative center concentration distributions for the north and south canal areas, respectively.

2. $\mathrm{HB} 4$ and HBl2 are representative of off-center concentration distributions for the north and south canal areas, respectively.

3. Canal depth and cross sectional profiles can be approximated with
$\mathrm{N}_{\mathrm{Z}}=\mathrm{A} \mathrm{e}^{-\mathrm{BZ}^{2}}$ and $\mathrm{N}_{\mathrm{X}}=\mathrm{A} \mathrm{e}^{-\mathrm{CX}}$ distribution functions, where $A, B$, and $C$ are empirically adjustable parameters.

4. The average specific gravity of the wet soil at the sample location is $2 \mathrm{~g} / \mathrm{cm}^{3}$ (125 $\mathrm{lb} / \mathrm{ft} \mathrm{t}^{3}$ ) and that the average soil water content is 258 [2].

It follows from assumption (3) that the total tritium in the canal can be estimated as

$N_{T}=2 \Delta Y N_{\infty o} \int_{0}^{\infty} \int_{0}^{\infty} e^{-B Z} e^{-C X^{2}} d x d z$

where $\Delta Y$ represents the length of the canal area contaminated and Noo the peak horizontal and vertical contamination. Upon integration of ( 1 ) and solving for the $C$ and $B$ parameters by curve-fitting to the empirical data for $\mathrm{HB} 3$ and $\mathrm{HB} 4$, a value of $3.1 \times 10^{4} \mu \mathrm{Ci} / \mathrm{ft}$ is obtained for $\mathrm{N}_{\mathrm{T}} / \Delta \mathrm{Y}$. It is next assumed that the entire length of the north canal, $2700 \mathrm{ft}$, and $2500 \mathrm{ft}$ of the south canal represent the contaminated zone. Thus it follows that the tritium inventory in the soil in the area of the Miaminteic Canal is approximately $162 \mathrm{Ci}$.

It is further estimated that the soil under the two ponds at the north end of the canal could contain as much as $23 \mathrm{Ci}$. This quantity is obtained by assuming that the contamination level is at least an order of magnitude lower in the ponds than the maximum found in the canal. This assumption is supported by both the HB series soil analyses for the north canal and previous soil analysis results for a sample location, SB8, in the south pond.

Thus the total tritium inventory for the canal/pond system is estimated to be 185 ci. Since the average bound/exchangeable 
ratio for all the $\mathrm{HB}$ series soil analyses was found to be 0.9 , it is estimated that $167 \mathrm{Ci}$ of the total inventory is in a bound form and only $18 \mathrm{Ci}$ are presently available for transfer to the aquifer via soil water migration.

\section{Affected aquifer volume and tritium inventory}

The area of the buried-valley aquifer affected by the canal contamination is assumed to be as shown in Figure 5 (enclosed in hashmarks) and represents a surface area of approximately $7 \times 10^{6} \mathrm{ft}^{2}$. This represents a $4.9 \times 10^{9}$ liter volume of water for a saturation thickness of 70 ft and a $35 \%$ porosity [3]. If the average tritium concentration in this area of the aquifer is taken to be 20 nci/liter, a total inventory of $98 \mathrm{ci}$ is estimated. This $20 \mathrm{nCi} / 1$ iter appears to be a reasonable average concentration based on present values for the wells in the affected area [3].

\section{Contamination character-}

\section{istics and behavior studies}

Several experiments were carried out to establish the identity of the radioactive species in the canal soil and to explore the physical and chemical nature of its carrier compound.

Initial studies involved confirming that the radioactivity observed by liquid scintillation counting in soil samples from the canal was due to tritium rather than some unknown radionuclide or scintillation counting anomaly. Using water samples from soil distillate and standard time dependent counting techniques, the possibility of chemiluminescence, bioluminescence, and scintillation enhancement was eliminated. A distillate water sample was also compared with a tritiated water standard, chlorine-36 and carbon-14 standards by the liquid scintillation counting channel ratio method. The tritiated water standard and the canal sample gave almost identical results, whereas there was no correlation between both the chlorine-36 and carbon-14 results and the tritiated water standard. To confirm that the active agent in the soil samples behaves as hydrogen, a reduction/oxidation train was assembled, and a sample of soil distillate was passed through it, collected with a glycol bubbler, and analyzed with a scintillation counter. Over $90 \%$ of the active agent followed the chemical path of hydrogen through the train. These data, together with the scintillation counting energy discrimination and channel ratioing data, rule out all other possible active agents and can be considered sufficient evidence to confirm the presence of tritium.

Early in the HB series soil sample analysis campaign, a water leach sample of HB3-2 was set aside as a long-term leach. study. The sample was in its third leach when set aside, so that the major portion of the exchangeable tritium had been removed, and any increase of tritium levels in the leach water was due to transfer from the bound to the exchangeable form. The results for a 60day period are shown in Figure 6. These data have been plotted as if the bound-toexchangeable transfer follows first-order kinetics, a reasonable premise on the basis of the linearity of the plot. If first-order kinetics can be used to describe this transfer rate, a physically reasonable half-time of $3 \mathrm{yr}$ is indicated. Thus one can calculate that, within the 


\section{Canal/aquifer}

\section{interaction model}

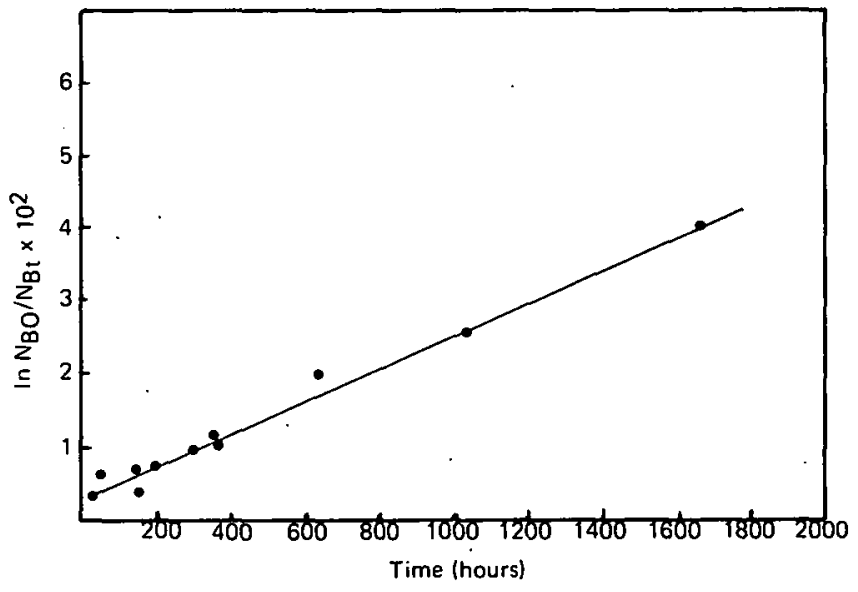

FIGURE 6 - In vitro transfer of tritium from bound to exchangeable form.

next year, as much as $30 \mathrm{Ci}$ of the tritium inventory in the canal will be converted to the exchangegable form that is capable of reaching the aquifer.

A Freon extraction was performed on an HBl3-2 aliquot to investigate the possibility that the tritium is bound in an organic compound. Freon 113, an oil and grease extractant used in EPA standard Procedure STORET No. 00556, was used to leach the soil samples in much the same way as the water leaches were performed. After over 14 days of contact between a $110^{\circ} \mathrm{C}$ dried soil sample and an approximately equal weight of Freon 113, less than 0.58 of the bound tritium was extracted. Thus the tritium does not appear to be bound as a nonvolatile hydrocarbon, vegetable oil, animal fat, wax, soap, grease, or similar material, all of which are soluble in Freon 113.
In order to better assess the effects and nature of the interaction between the tritium in the Miami-Erie Canal and the buriedvalley aquifer, a three-compartment model was used. It should be pointed out that any such model is a gross simplification of a very complex interaction and can only be used for explaining qualitative features. Some of the complicating features of this interaction system are: (1) the tritium contamination distribution in the canal appears to be very heterogeneous; (2) the canal environs, a man-made waterway in the first place, have undergone a number of alterations which make it impossible to quantify the percolation rate of water from the canal to the aquifer; and (3) the Dames \& Moore [3] hydrological study shows that the aquifer is neither homogeneous nor isotropic. Because of these features, a rigorous evaluation of the tritium levels and their rates of change would need to be made on the basis of each individual well, using the appropriate terms for the drawdown zone for that particular well and including the cross terms due to other well fields. Such an approach was not warranted, since it was both outside the scope of this study and impractical on the basis of the accuracy and completeness of the available hydrological data.

To arrive at a qualitative model for the canal/aquifer interaction within the boundaries of the above limitations the following assumptions were made:

1. Contamination incident or incidents occurred as discrete events - acute versus chronic exposure. The sharp vertical 
distribution profiles found for the tritium in the canal support this assumption.

2. No significant releases to the canal via the drainage ditch have occurred since the installation of a ditch monitoring station in 1971.

3. The transport kinetics can be approximated by first-order expressions. This is obviously true for the nuclear decay terms and is reasonable for those terms involving water transport, since selfdiffusion of water in soil has been found to be quite slow [5].

4. Sufficient time has elapsed since the contamination incident and the relative values of the rate constants are such that the quantity in the exchangeable compartment has approached steady-state. This assumption simplifies the mathematical analysis of the model and is reasonable on the basis of the relatively constant, low quantities of tritium found in the exchangeable fraction of the HB series samples.

The three-compartment model shown in Figure 7 has been postulated on the basis of the above assumptions, the results from the HB series canal soil analyses, the inventory estimates, and the Dames \& Moore hydrological data. The symbol. $\lambda_{N}$ represents the nuclear decay rate for tritium $\left(y^{-1}\right), \lambda_{B}$ is the transfer rate from the bound state to the water-exchangeable state $\left(y^{-1}\right), \lambda_{E}$ is the transfer rate from the exchangeable compartment to the aquifer $\left(y^{-1}\right)$, and $R$ is the effective recharge rate of the aquifer (liter $y^{-1}$ ) for an aquifer of effective volume $v$ (liter).

The rates of change for tritium in each of the compartments are:

$\begin{aligned} \frac{d N_{B}}{d t} & =-\left(\lambda_{B}+\lambda_{N}\right) N_{B} \\ \vdots & \\ \frac{d N_{E}}{d t} & =\lambda_{B} N_{B}-\left(\lambda_{N}+\lambda_{E}\right) N_{E}\end{aligned}$

$\frac{\mathrm{dN}_{\mathrm{A}}}{\mathrm{dt}}=\lambda_{E^{N}}-\left(\frac{\mathrm{R}}{\mathrm{V}}+\lambda_{\mathrm{N}}\right) \mathrm{N}_{\mathrm{A}}$

If the steady-state assumption is applied to equation (3) and equation (2) is integrated between the limits of $\mathrm{N}_{B O}$ (the initial quantity of tritium released in the bound form) and $\mathrm{N}_{B}$, the $\mathrm{N}_{E}$ variable can be eliminated from equation (4) to give

$\frac{\mathrm{dN}_{\mathrm{A}}}{\mathrm{dt}}=\left(\frac{\lambda \mathrm{B} \lambda \mathrm{E}}{\lambda_{\mathrm{N}}+\lambda_{E}}\right) \mathrm{N}_{\mathrm{B}}-\left(\frac{\mathrm{R}}{\mathrm{V}}+\lambda_{\mathrm{N}}\right) \mathrm{N}_{\mathrm{A}}$

or

$\frac{d N_{A}}{d t}=\left(\frac{\lambda_{B} \lambda_{E} N_{B O}}{\lambda_{N}+\lambda_{E}}\right) e^{-\left(\lambda_{B}+\lambda_{N}\right) t}-\left(\frac{R}{V}+\lambda_{N}\right) N_{A}$

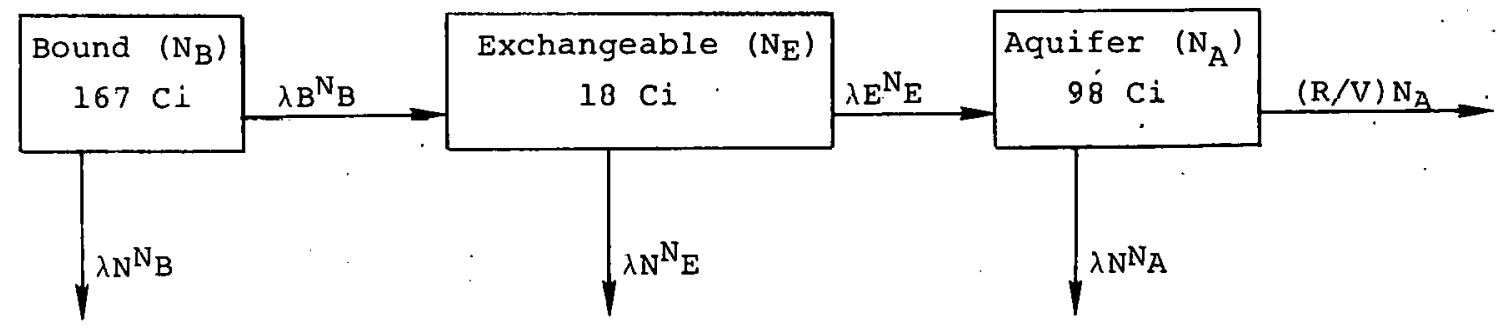

FIGURE 7 - Three-compartment migration model. 
The time dependency of the tritium content of the aquifex is thus obtained by integration of equation (6) to give

$$
\begin{aligned}
N_{A}= & \frac{\lambda B \lambda E N B O}{\left(\lambda_{N}+\lambda_{E}\right)\left(\lambda_{B}-R / V\right)}\left[e^{-\left(R / V+\lambda_{N}\right) t}\right. \\
& \left.-e^{-\left(\lambda_{B}+\lambda_{N}\right) t}\right] .
\end{aligned}
$$

Thus in principle, if the rate constants for the various interactions were known, one could rigorously describe the timedependent behavior of the tritium in the aquifer. Unfortunately, $\lambda E$ is not known, and $R / V$ and $\lambda B$ can only be estimated with a great deal of uncertainty. Attempts were made to estimate $\lambda E$, but the resultant expressions for $\mathrm{N}_{\mathrm{A}}$ as a function of time were not consistent with the observed behavior of Mound and Miamisburg wells for the period 1971 through 1976. However, the dependencies and interactions described by expressions (5) and (7) can be used. to assess the effects of various actions, such as removing the source term by excavating the tritium contaminated zone from the canal and/or increasing the aquifer recharge rate by pumping.

A generalized plot of equation (7) is shown in Figure 8 . The values for the rate constants were chosen on the basis of being physically reasonable estimates that result in a time dependency that is comparable to those observed for the tritium concentrations in the Mound and Miamisburg City wells [3]. The variables $\lambda_{E}$ and $\mathrm{N}_{\mathrm{BO}}$ have been collected into an arbitrary constant, $K$. Since $K$ is part of the pre-exponential in equation (7), its value does not affect the general features of the curve, only the position of the ordinate.
The general features of the relationship represented by equation (5) and shown in Figure 8 are such that the function will go through a maximum at some time after the contaminating event. Before the maximum, the $\mathrm{N}_{B}$ term dominates, and after the maximum, the $\mathrm{N}_{A}$ term dominates. The dominance of the latter steadily increases with time. These features are the most useful for this study, since they relate to the possible courses of action for lowering the aquifer tritium concentration. 'Thus both increasing the recharge rate $\mathrm{R} / \mathrm{V}$ (pumping) and decreasing the source term $\mathrm{N}_{\mathrm{B}} \lambda_{\mathrm{B}}$ (physical removal) can reduce the time needed to reach a certain contamination level in the aquifer. The latter action is more effective if taken as early as possible after the maximum has been passed. The dotted curves in Figure 8 represent the effect of such source removal action taken 3,6 , and $10 \mathrm{yr}$ āfter the contamination incident.

\section{Conclusion and discussion}

The following conclusions can be drawn on the basis of the data from the HB seiries canal soil analysis campaign, the Dames \& Moore hydrology studies, and the models and analyses put forth in this report.

1. Tritium is the canal contaminant.

2. As of the end of 1976 a total tritium inventory of approximately $200 \mathrm{Ci}(0.02 \mathrm{~g})$ is in the $5200 \mathrm{ft}$ stretch of the Miami-Erie Canal and the adjoining ponds west of the Mound Facility site.

3. Approximately $90 \%$ of the tritium in the canal soil is in a bound, not water exchangeable, form. 


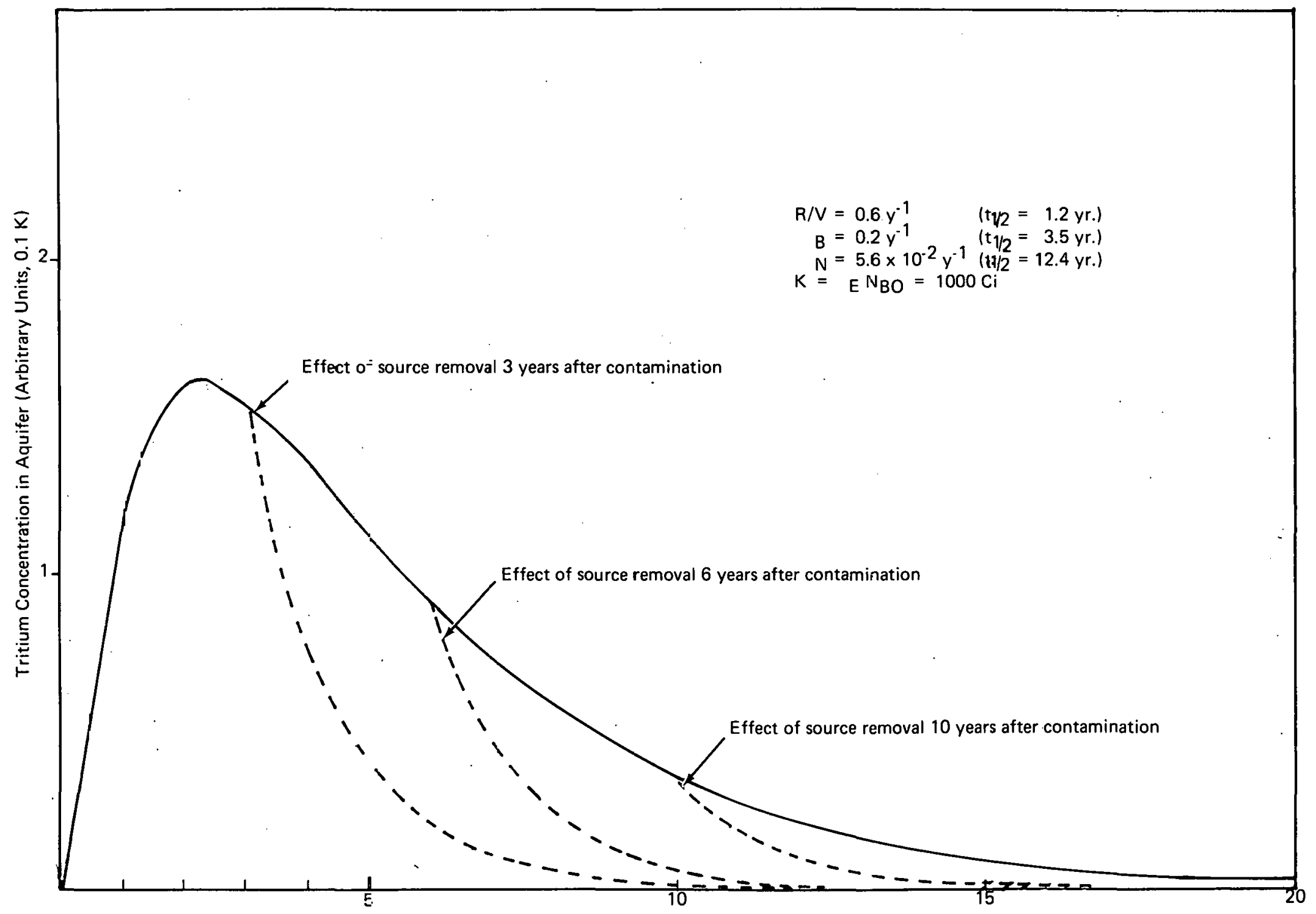


4. In general, the contamination is highly concentrated in the center of the canal water-channel and within $2 \mathrm{ft}$ of the surface. The contamination levels are highest near the Mound drainage ditch and canal confluence.

5. The tritium contamination distributions resemble the plutonium-238 contamination distributions, which were attributed to a particulate sedimentation deposition mechanism.

6. The bound-to-exchangeable transfer half-time is approximately $3 \mathrm{yr}$ based on preliminary in vitro data.

7. The tritium in the canal area could contribute as much as $30 \mathrm{Ci}$ to the aquifer in the next year.

8. The three-compartment canal/aquifer interaction model and the general decreasing trends recorded for the tritium concentration in on-site and surrounding wells since 1971 indicate that the time of maximum influence by the canal tritium is well past and the aquifer recharge dominates. Thus it appears that the most efficacious time for removing the tritium from the canal has passed. Moreover, pumping at a nominal $500 \mathrm{gal} / \mathrm{min}$ more than offsets the present, magnitude of the source term estimated in (7) above. The relative cost of such pumping is minor compared to the cost of removing the tritium from the canal.

\section{References}

1. B. M. Farmer, B. Robinson and D. G. Carfagno, "Annual Environmental Monitoring Report: Calendar Year 1976," MLM-2416 (April 25, 1977) .

2. D. R. Rogers, "Mound Laboratory Environmental Plutonium Study," MLM-2249 (September 15,1975$)$.

3. Dames \& Moore, Consultants in The Environmental and Applied Earth Sciences, Sciences, Cincinnati, Ohio, private communication.

4. C. W. Francis, Oak Ridge National Laboratory, Oak Ridge, Tennessee, private communication.

5. D. S. Sasscer, C. F. Jordan and J.R. Kline, 1971, in "Radionuclides in Ecosystems," Proceedings of the Third National Symposium on Radioecology (Edited by D. J. Nelson), CONF-710501-Pl (USAEC) p. 915.

\section{Acknowledgement}

The authors wish to thank Elizabeth Wallace for her valuable assistance on the soil sample analyses and Warren Sheehan for his advice and support in the radiocounting portion of this work. 


\section{Appendix A}

Soil analysis results for $\mathrm{HB}$ series 
Tritium Concentration $(\mathrm{uCi} / \mathrm{kg})$

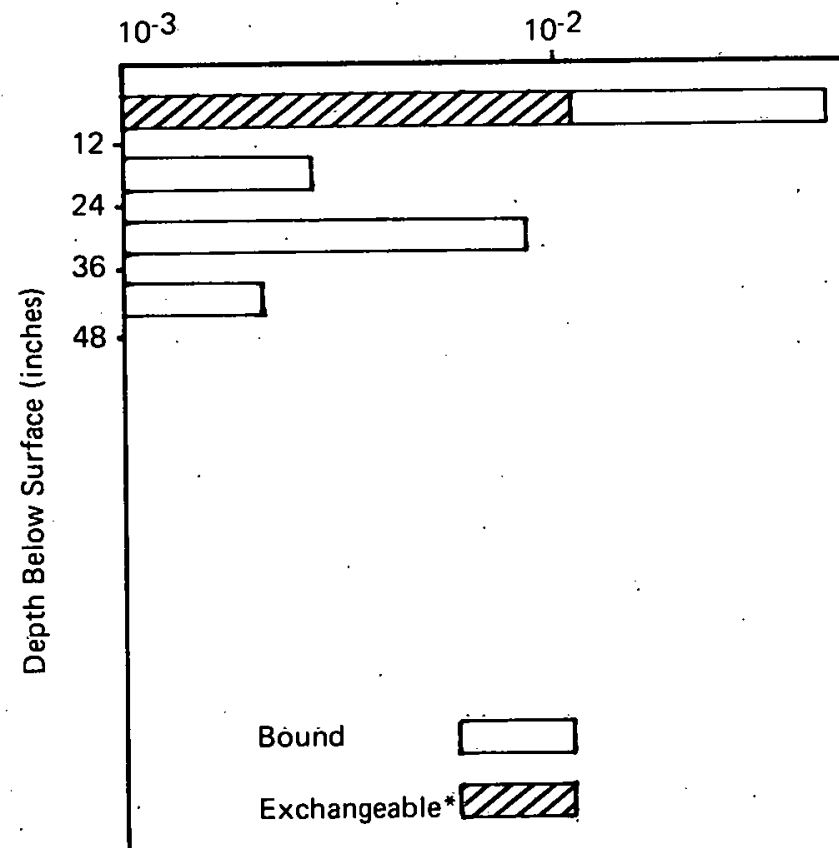

$10^{-1}$

"All exchangèable tritium concentration below the 12" sample were below the detection limits of the analysis procedure.

FIGURE.A-1 - HB2 north canal (150.ft north of dam, $15 \mathrm{ft}$ west of center).

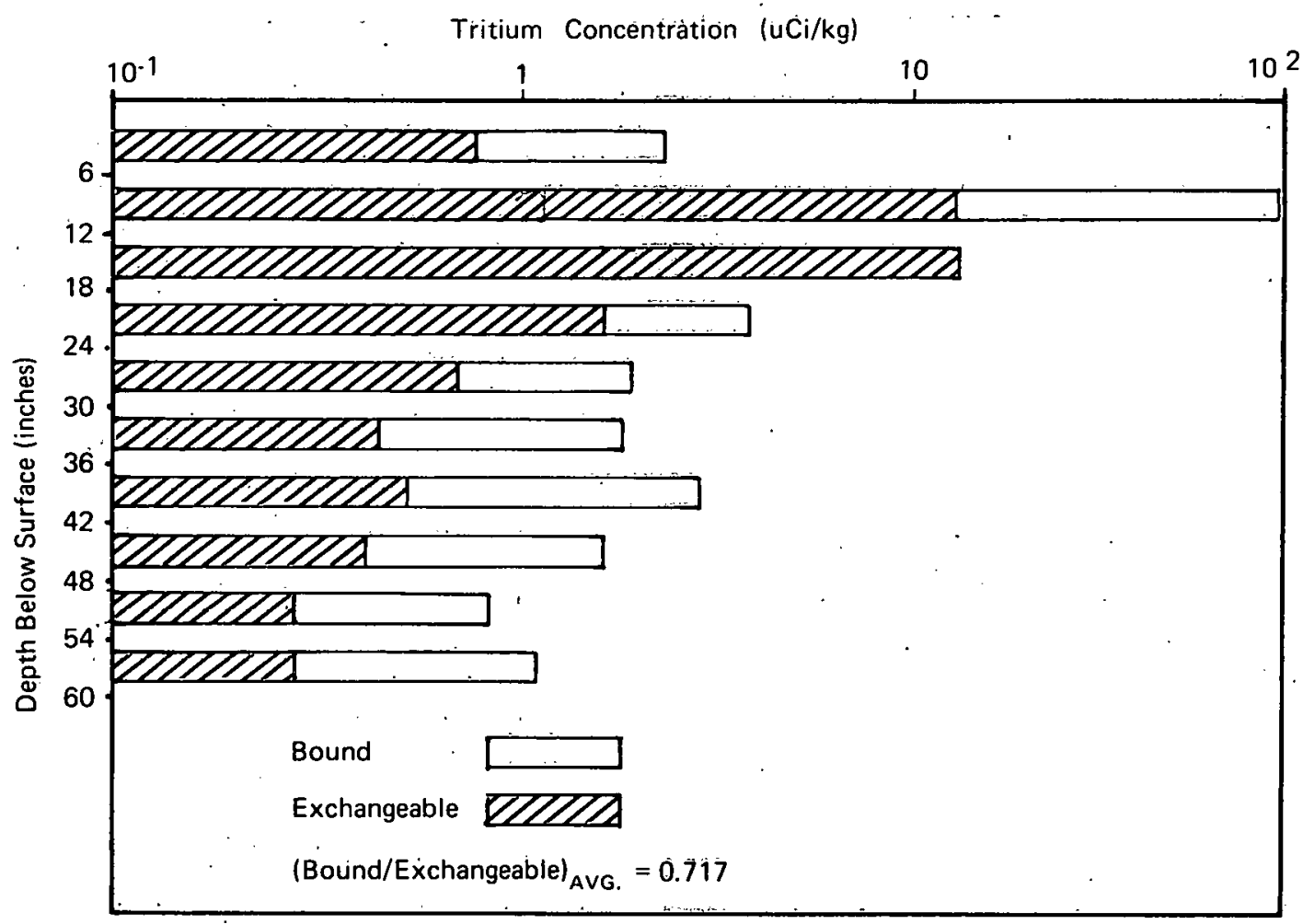

FIGURE A-2 - HB3 north canal (center, $150 \mathrm{ft}$ north of dam). 


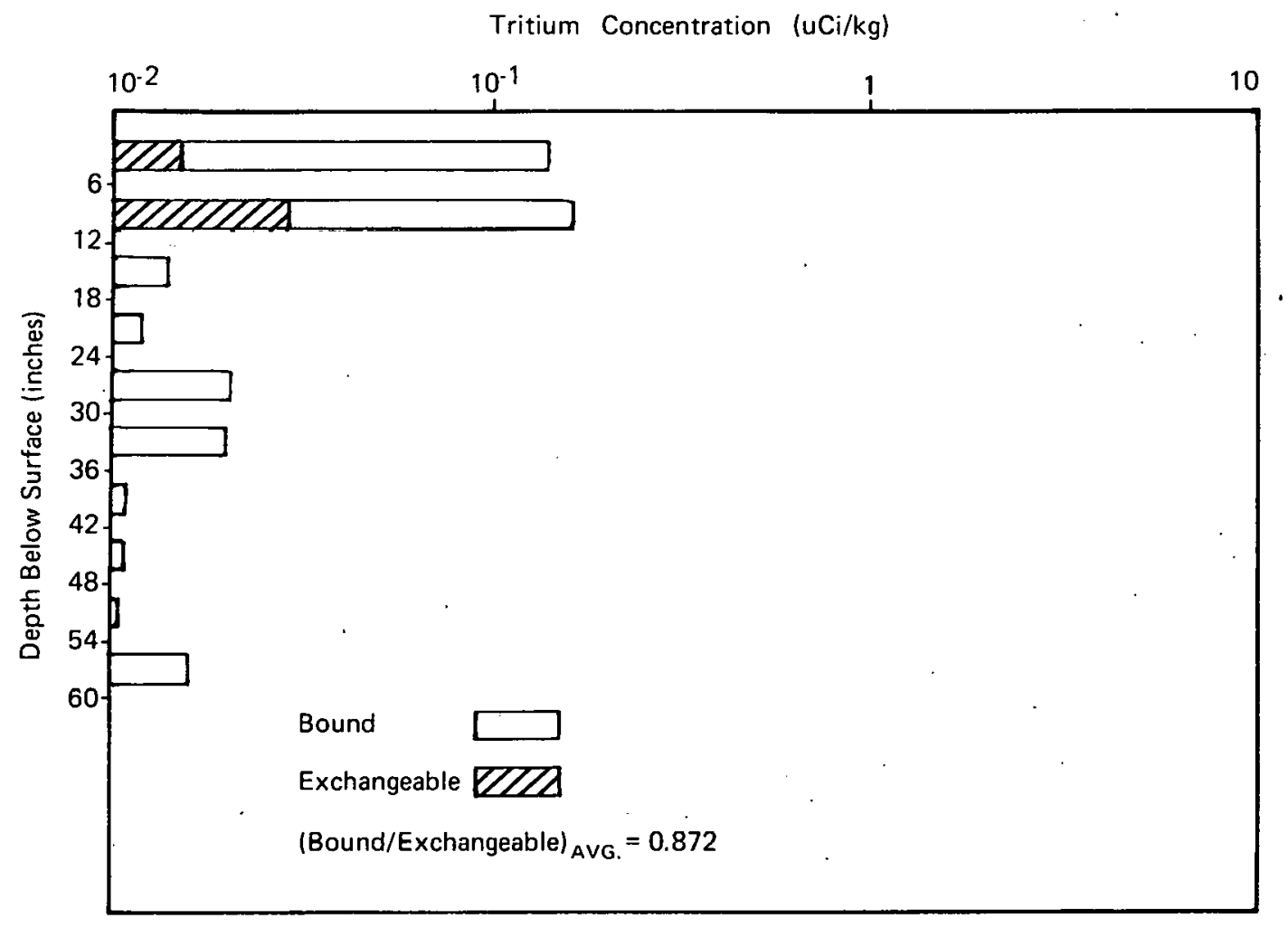

FIGURE A-3 - HB4 north canal $(15 \mathrm{ft}$ east of center, $150 \mathrm{ft}$ north of dam).

Tritium Concentration (uCi/kg)

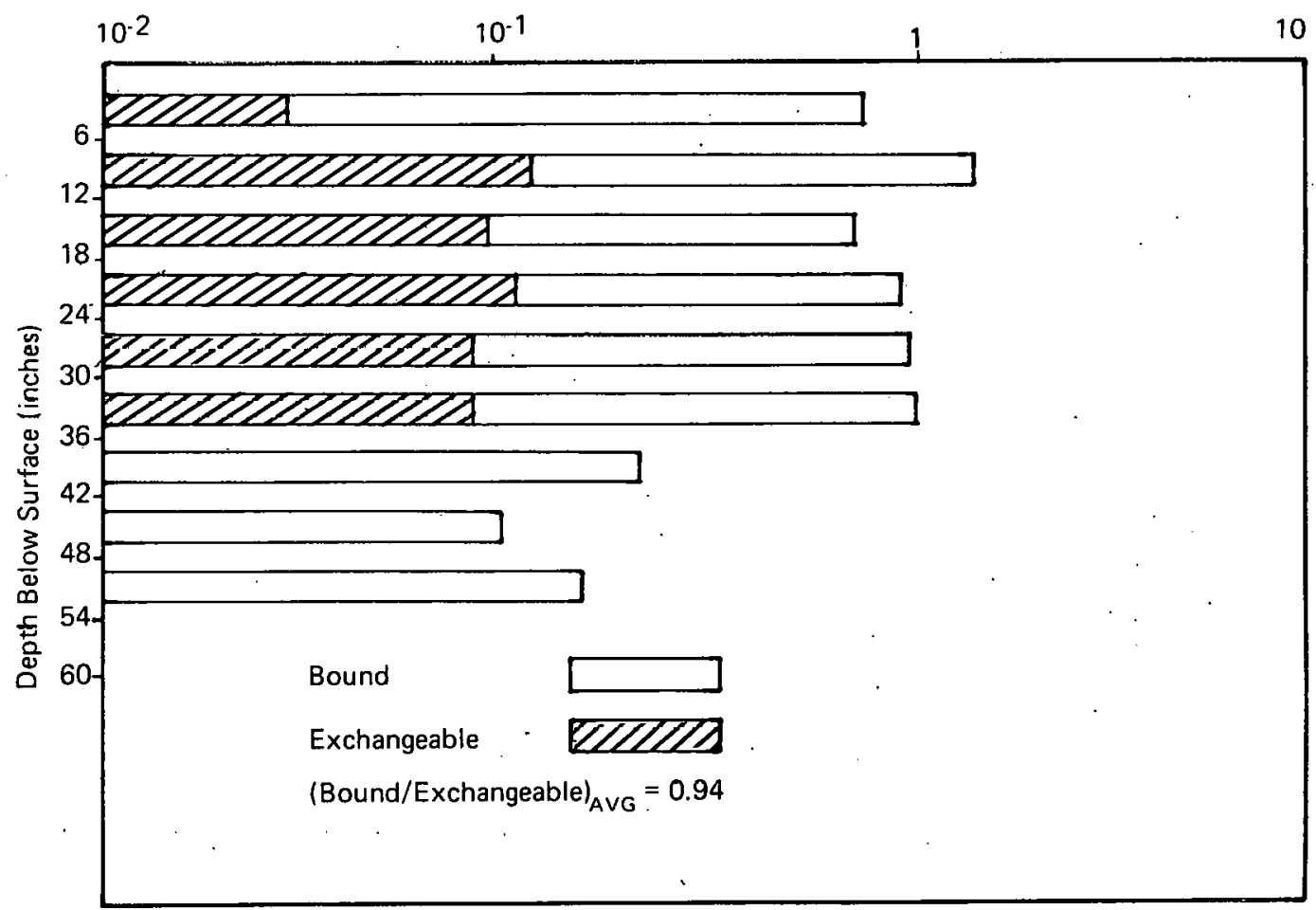

FIGURE A-4 - HB6 north canal (center, $2600^{\circ} \mathrm{ft}$ north of dam). 


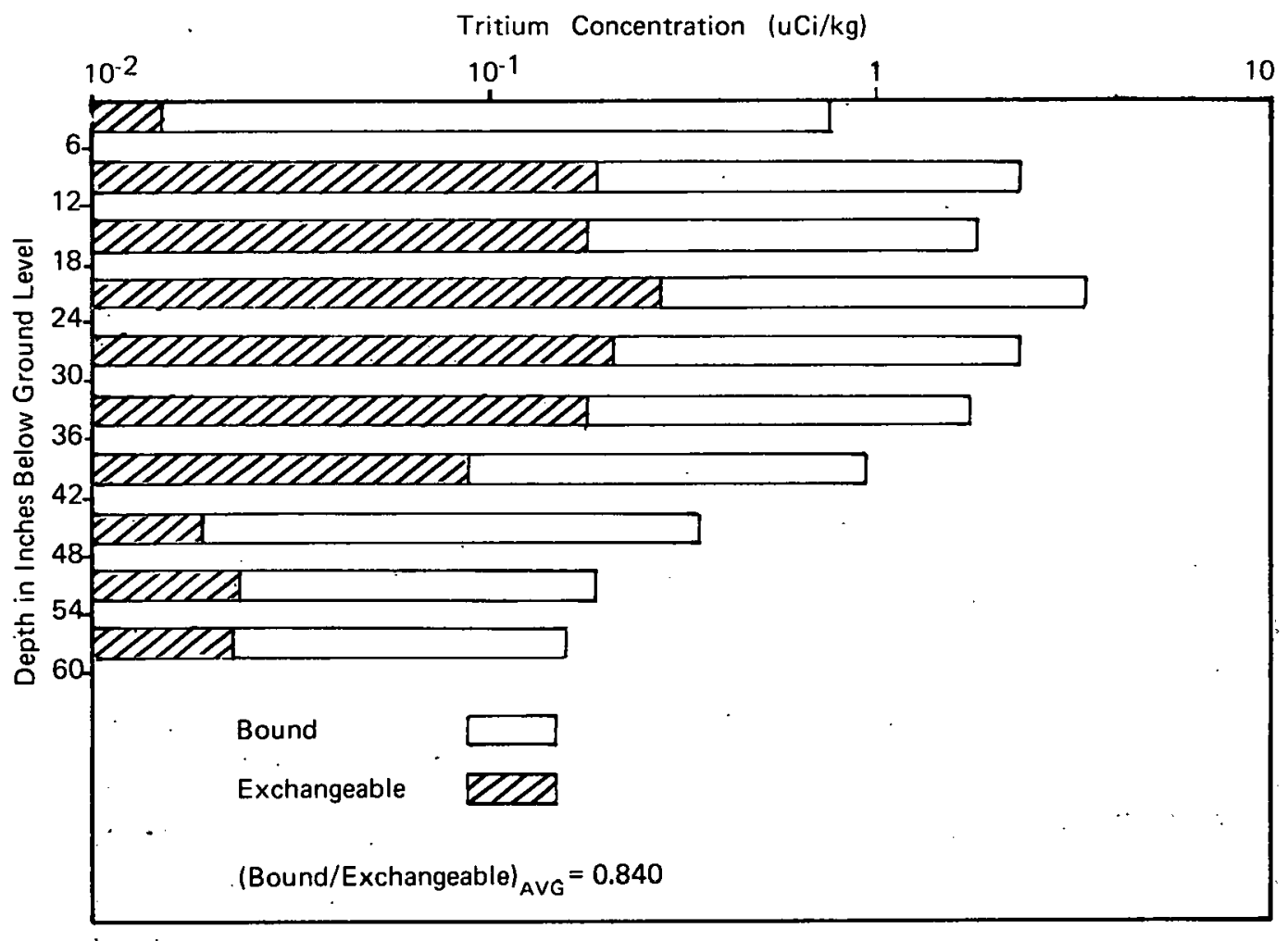

FIGURE A-5 - HB7 north canal ( $3 \mathrm{ft}$ east of center, $2600 \mathrm{ft}$ north of dam).

Tritium Concentration ( $\mathrm{uCi} / \mathrm{kg}$ )

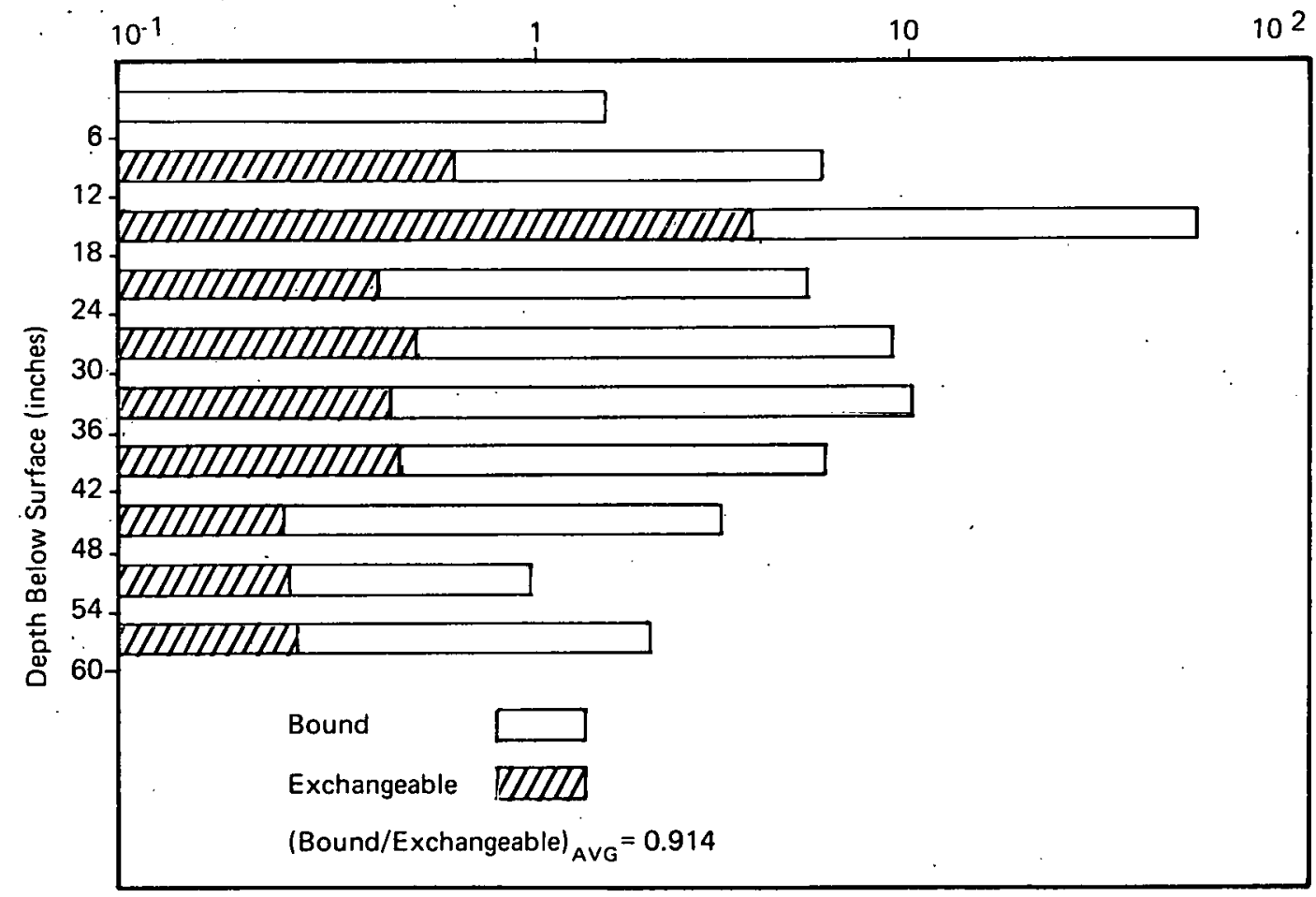

FIGURE A-6 - HB8 south canal (14 ft west of center, $900 \mathrm{ft}$ south of dam). 


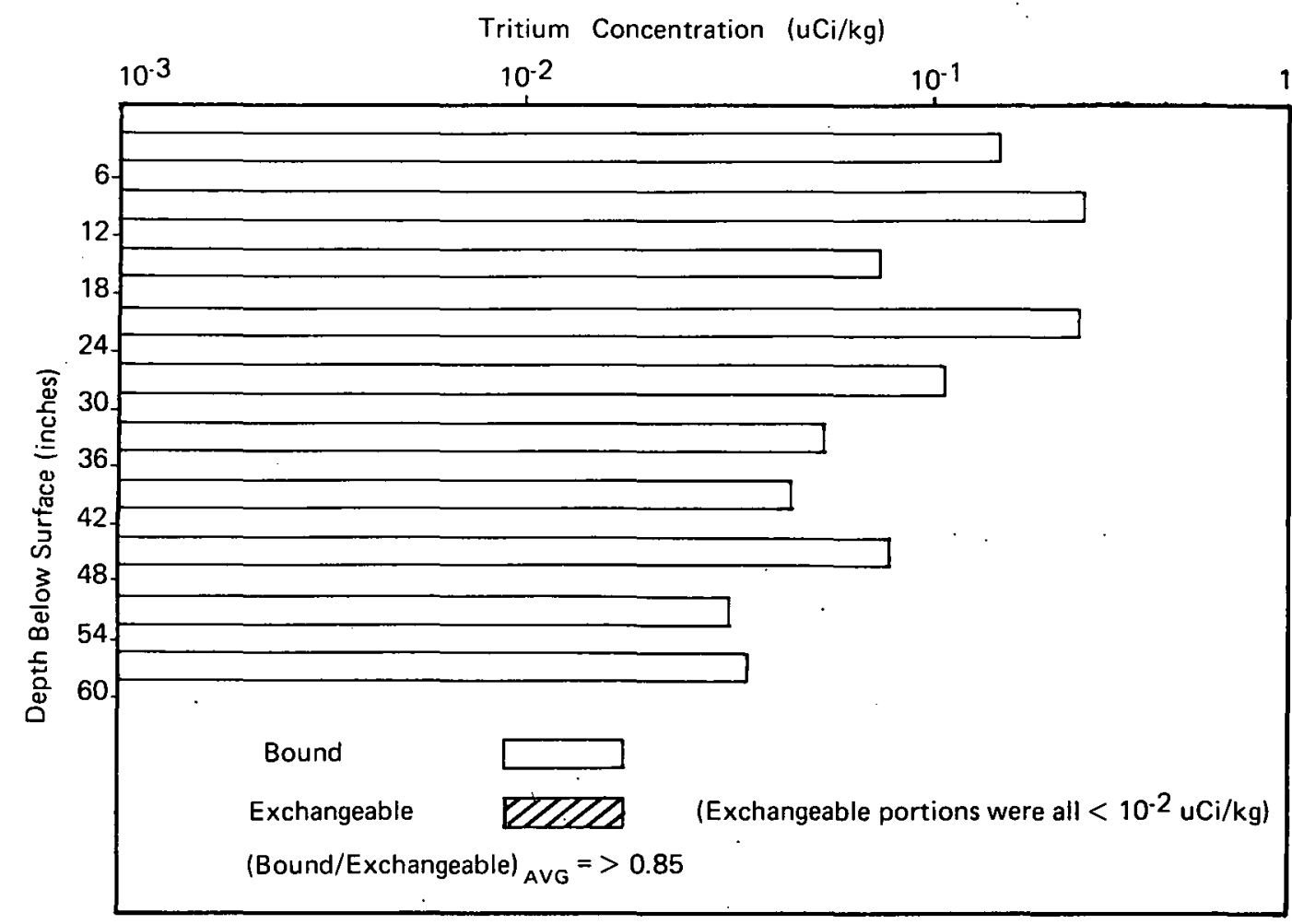

FIGURE A-7 - HB9 south canal (12 ft east of center; $900 \mathrm{ft}$ south of dam).

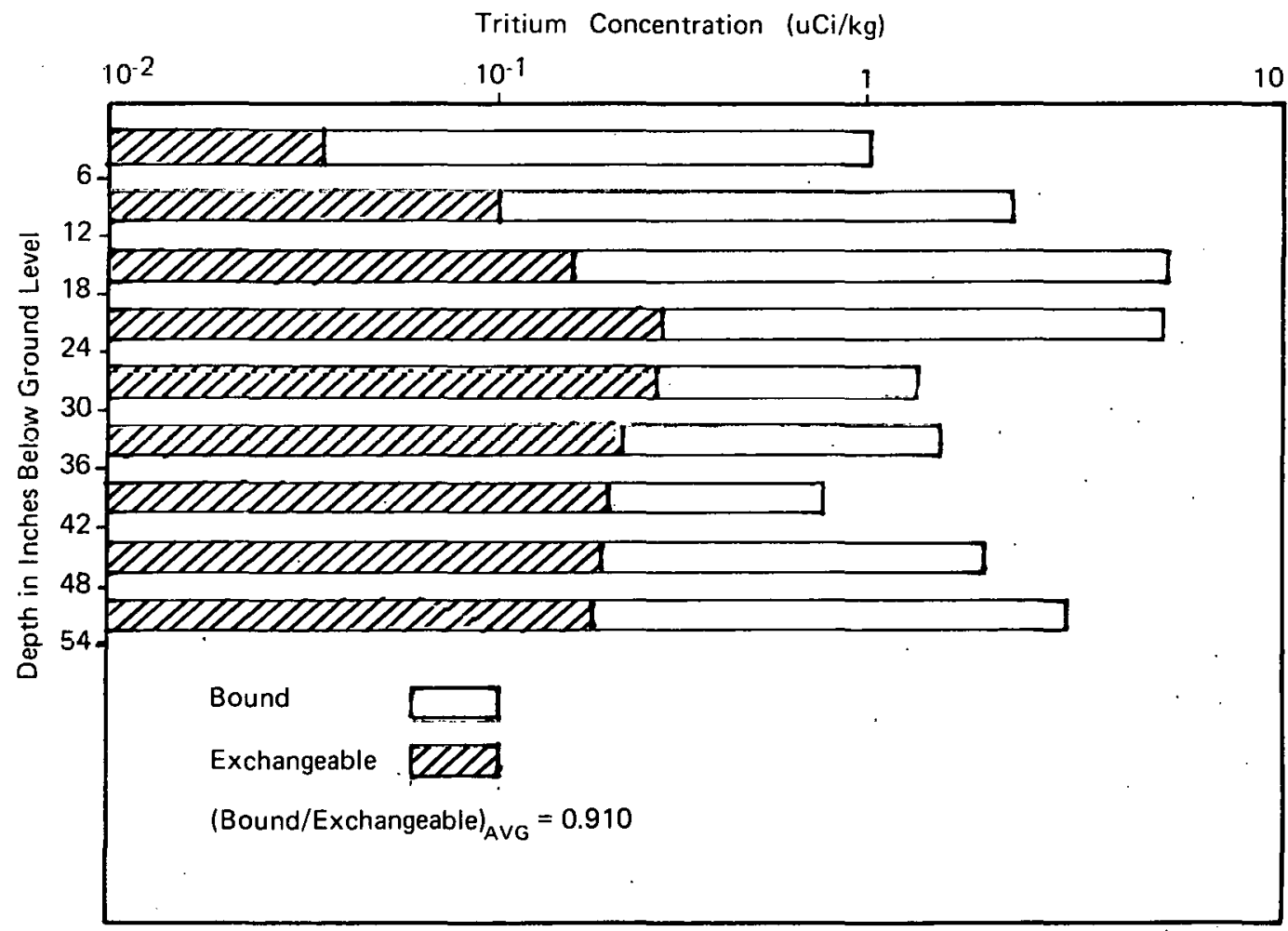

FIGURE A-8 - HB10 south canal (center, $900 \mathrm{ft}$ south of dam). 


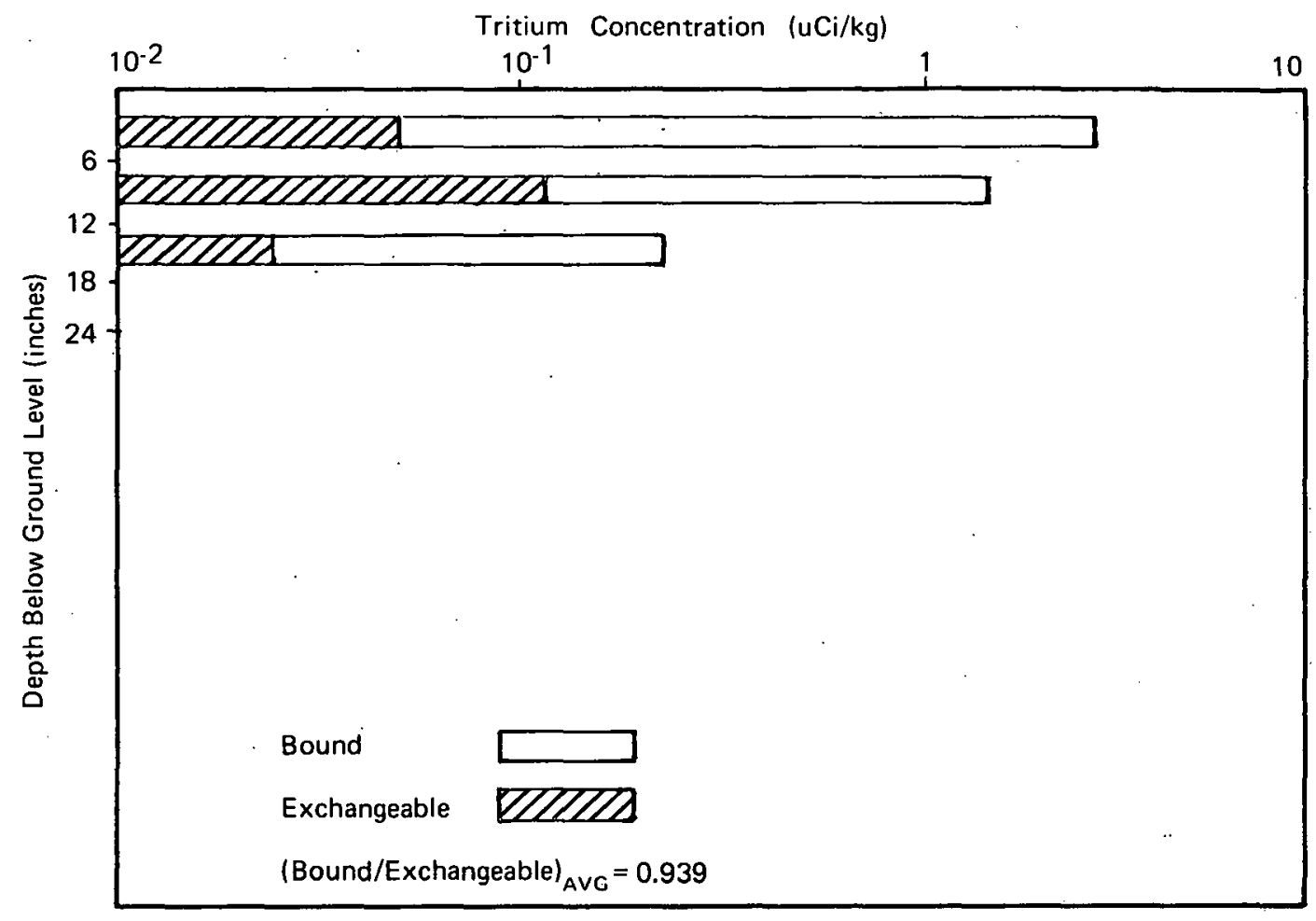

FIGURE A-9 - HB11 south canal ( $9 \mathrm{ft}$ west of center, $150 \mathrm{ft}$ south of dam).

Tritium Concentration (uCi $/ \mathrm{kg}$ )

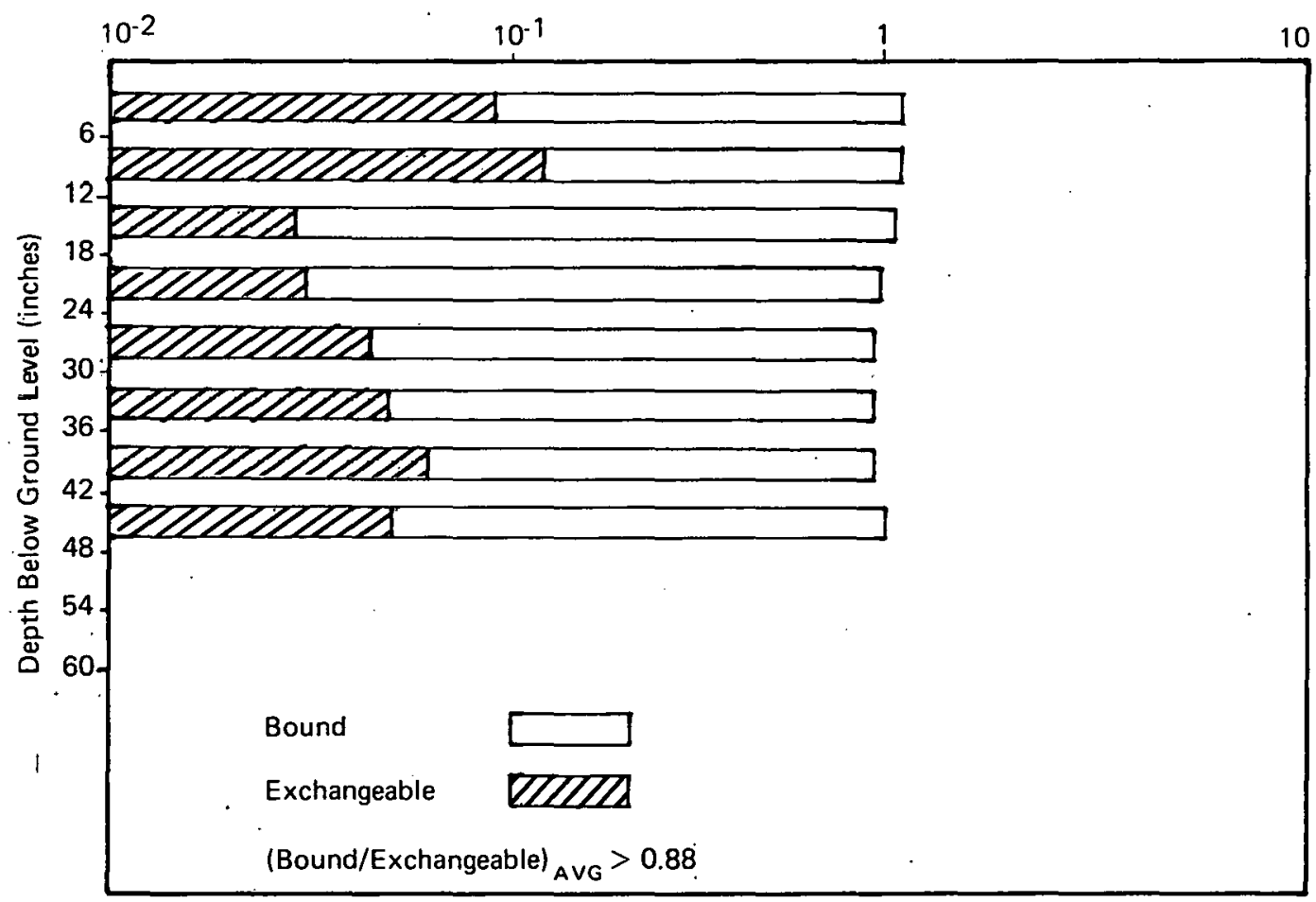

FIGURE A-10 - HB12 south canal ( $7 \mathrm{ft}$ east of center, $150 \mathrm{ft}$ south of dam). 


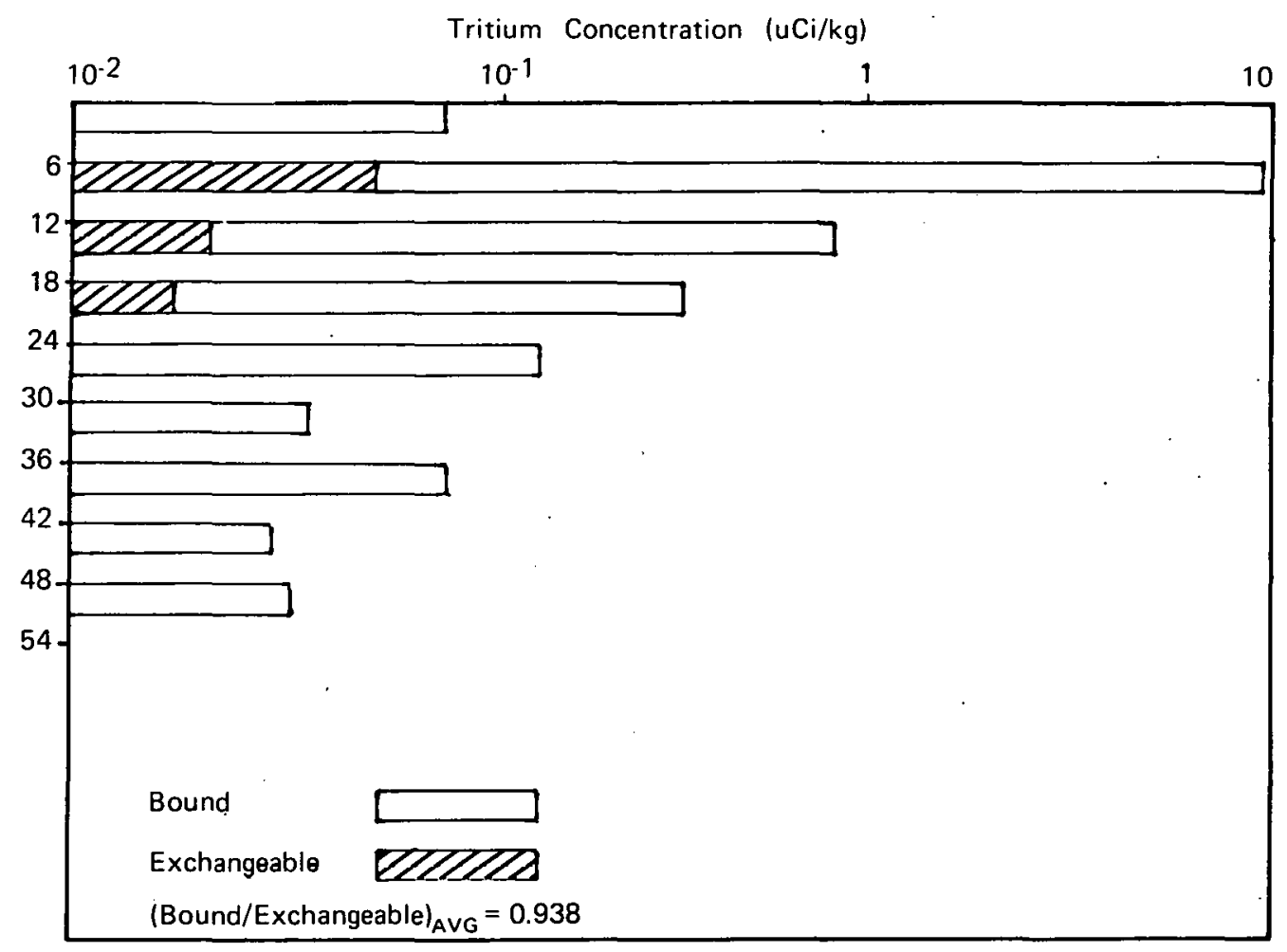

FIGURE A-11 - HBI3 south canal (center, $150 \mathrm{ft}$ south of dam). 


\title{
Distribution
}

\author{
EXTERNAL
}

TIC, UC-11. (225)

R. K. Flitcraft, MRC

Monsanto Library, St. Louis

J. A. Chacon, DAO

\section{INTERNAL}

W. T. Cave

C. W. Huntington.

L. V. Jones

C. J. Kershner

B. R. Kokenge

J.R. Mcclain

H. E. Meyer

T. B. Rhinehammer

M. L. Rogers

D. R. Spangler

R. E. Vallee

Publications

Library (15) 